\title{
Rare expression of T-cell markers in classical Hodgkin's lymphoma
}

\author{
Alexandar Tzankov ${ }^{1}$, Caroline Bourgau ${ }^{2}$, Alexandra Kaiser ${ }^{1}$, Annette Zimpfer ${ }^{2}$, \\ Robert Maurer ${ }^{3}$, Stefano A Pileri ${ }^{4}$, Philip Went ${ }^{2}$ and Stephan Dirnhofer ${ }^{2}$ \\ ${ }^{1}$ Institute of Pathology, Medical University of Innsbruck, Innsbruck, Austria; ${ }^{2}$ Institute of Pathology, \\ University Hospital Basel, Basel, Switzerland; ${ }^{3}$ Institute of Pathology, Triemli Hospital, Zurich, Switzerland \\ and ${ }^{4}$ Pathologic Anatomy \& Lymphoma Unit, Institute of Hematology and Clinical Oncology, 'L\&A \\ Seràgnoli', University of Bologna, Bologna, Italy
}

\begin{abstract}
Hodgkin's and Reed-Sternberg cells of classical Hodgkin's lymphoma are primarily of B-cell origin, although there are instances of T-cell antigen expression suggesting T-cell origin. We comprehensively analyzed expression of various T-cell antigens in 259 classical Hodgkin's lymphoma cases using the tissue microarray technique. Expression of the T-cell antigens CD2, CD3, CD4, CD5, CD7 and CD8 was assessed by immunohistochemistry. Hodgkin's and Reed-Sternberg cells of T-cell marker-positive cases were microdissected and analyzed by a multiplex polymerase chain reaction for clonal immunoglobulin heavy chain- and T-cell receptor $\gamma$ gene rearrangements. In all, 12 cases $(5 \%)$ expressed at least one T-cell marker in the following order: CD2 in 11 cases, CD4 in five, CD3 in two, and CD5 and CD8 in one case each; there were no CD7-positive cases, and five cases (2\%) expressed more than one T-cell antigen. In positive cases, a mean fraction of $40 \%$ of the Hodgkin's and Reed-Sternberg cells (range 20-100\%) expressed the analyzed T-cell markers. Two cases $(<1 \%)$ evidenced clonal T-cell receptor $\gamma$ gene rearrangement. Phenotypic expression of T-cell antigens in Hodgkin's and Reed-Sternberg cells of classical Hodgkin's lymphoma is rare $(5 \%)$, while genotypically, less than $1 \%$ of classical Hodgkin's lymphomas are of possible T-cell origin. Therefore, T-cell antigen expression on Hodgkin's and Reed-Sternberg cells is aberrant in the majority of cases and only infrequently classical Hodgkin's lymphomas are of T-cell origin.
\end{abstract}

Modern Pathology (2005) 18, 1542-1549. doi:10.1038/modpathol.3800473; published online 29 July 2005

Keywords: classical Hodgkin's lymphoma; T-cell markers; tissue microarray; clonality

Molecular studies suggest that Hodgkin's and ReedSternberg cells of almost all classical Hodgkin's lymphomas originate from germinal center or postgerminal center B cells. ${ }^{1-3}$ Phenotypically, depending on the method used and antibodies applied, 5 to $100 \%$ of Hodgkin's and Reed-Sternberg cells express B-cell markers such as CD19, CD20, CD40, CD79a, CD138, BCL6, BSAP and MUM1 (reviewed in Pileri et $a l^{4}$ and Tzankov et $\left.a l^{5,6}\right)$. Moreover, in patients with composite classical Hodgkin's lymphoma/B-cell non-Hodgkin's lymphoma, Hodgkin's and Reed-Sternberg cells and B-non-Hodgkin's lymphoma cells appear to be clonally related. ${ }^{7-11}$

Interestingly, a distinct proportion of classical Hodgkin's lymphomas express T-cell- or cytotoxic

Correspondence: Dr S Dirnhofer, MD, Institute of Pathology, University Hospital Basel, Schönbeinstrasse 40, Basel CH-4031, Switzerland.

E-mail: sdirnhofer@uhbs.ch

Received 1 June 2005; revised 29 June 2005; accepted 30 June 2005; published online 29 July 2005 markers, and some of them seem to be derived from $\mathrm{T}$ cells. ${ }^{12-27}$ Immunophenotyping on frozen and paraffin-embedded material, flow cytometry and cell culture analyses showed that 5 to $60 \%$ of classical Hodgkin's lymphomas express T- and NKcell markers such as T-cell receptor $\beta$-chains, CD3, CD4, CD5, CD6, CD7, CD8, CD25, granzyme B and TIA-1. ${ }^{12-17,19,22-24,27,28}$ In a small number of cases, the expression of T-cell markers was corroborated by analysis of the T-cell receptor genes for clonal rearrangements on microdissected single Hodgkin's and Reed-Sternberg cells. ${ }^{23,27,29}$ However, only three cases have been shown thus far to be of unequivocal T-cell origin. ${ }^{23,27}$ Moreover, there are controversial data on clonal relationships between Hodgkin's and Reed-Sternberg cells and T cells in patients with composite classical Hodgkin's lymphoma/T-nonHodgkin's lymphoma, ${ }^{20,30}$ with most cases being of different clonal origin. ${ }^{31-33}$ In addition to the implications for the tumor biology and histogenesis of classical Hodgkin's lymphoma, T-cell marker expression in Hodgkin's and Reed-Sternberg cells 
can lead to serious differential diagnostic difficulties to peripheral T-cell lymphoma, particularly to anaplastic large-cell lymphoma. ${ }^{4,14,18}$

To systematically analyze the expression and prognostic significance of a broad panel of T-cell markers (CD2, CD3, CD4, CD5, CD7 and CD8), we performed an immunophenotypic study on our recently published classical Hodgkin's lymphoma tissue microarray that was previously analyzed for the differential expression of B-cell markers and cell-cycle-regulating proteins. ${ }^{6,34,35}$ Positive cases underwent further laser-capture microdissection of Hodgkin's and Reed-Sternberg cells for molecular investigation of immunoglobulin heavy chain- and T-cell receptor $\gamma$ gene rearrangements to establish the B- or T-cell histogenesis of Hodgkin's and ReedSternberg cells at single-cell level.

\section{Materials and methods}

\section{Patients}

In all, 330 paraffin-embedded classical Hodgkin's lymphoma tissue samples were included in this study. The cases covered all histological subtypes of the World Health Organization classification, ${ }^{36}$ as described previously. ${ }^{6,34,35}$ Patient characteristics, definition of clinical response, relapses, as well as overall and disease-specific survival were recently reported. ${ }^{35}$

\section{Construction of Tissue Microarray}

Construction of the tissue microarray was performed as described previously. ${ }^{6,34}$ Only cases containing at least two morphologically unequivocal CD30-positive Hodgkin's and Reed-Sternberg cells were included.

\section{Immunohistochemistry}

The tissue microarray slides were immunohistochemically stained using an automated immuno- stainer (Nexes, Ventana, USA). The primary antibodies and antigen retrieval techniques are listed in Table 1. Bound secondary antibodies were visualized by standard avidin-biotin-peroxidase technique using diaminobenzidine as chromogen. For the T-cell markers CD2, CD3, CD4, CD5, CD7 and CD8, continuous membranous staining in $\geq 20 \%$ of Hodgkin's and Reed-Sternberg cells was considered positive. Cases containing less than 10 Hodgkin's and Reed-Sternberg cells were evaluated as described previously, that is, at least $50 \%$ of the Hodgkin's and Reed-Sternberg cells had to demonstrate positive staining. ${ }^{35}$ Special attention has been paid to Hodgkin's and Reed-Sternberg cells rimmed by $\mathrm{T}$ cells in order to assess true T-cell antigen expression in the neoplastic rather than in the adjacent $\mathrm{T}$ cells. Three investigators (AT, CB, SD) independently and carefully evaluated the cases. The few equivocal cases were discussed on a double-headed microscope in two consecutive runs. All classical Hodgkin's lymphoma cases expressing any T-cell marker on the tissue microarray were further analyzed by staining for the above-mentioned markers and additionally for BSAP, CD15, CD20, CD30, CD45RA, ALK-1 and EMA on conventional sections (provided paraffinembedded material was available) and selected for laser-capture microdissection of Hodgkin's and Reed-Sternberg cells. Quantification of BSAP expression was performed as described by Torlakovic and co-authors. ${ }^{37}$

\section{Laser-Capture Microdissection of Hodgkin's and Reed-Sternberg Cells}

Laser-capture microdissection was performed as recently described. ${ }^{8}$ In all, 75-120 Hodgkin's and Reed-Sternberg cells were collected per sample. In all cases, Hodgkin's and Reed-Sternberg cells were isolated in two subsequent runs to perform duplicate molecular analyses.

Table 1 Antibodies and antigen retrieval techniques used

\begin{tabular}{|c|c|c|c|}
\hline Antibody & Source & Dilution & Antigen retrieval \\
\hline BSAP & Transduction Lab. & $1: 30$ & EDTA pH8, microwave oven, $800 \mathrm{~W}, 3 \times 5 \mathrm{~min}$ \\
\hline $\mathrm{CD} 2$ & Novocastra & $1: 100$ & Citrate buffer $\mathrm{pH} 6$, wet autoclave, $121^{\circ} \mathrm{C}, 5 \mathrm{~min}$ \\
\hline CD3 & DAKO & $1: 50$ & Citrate buffer $\mathrm{pH} 6$, wet autoclave, $121^{\circ} \mathrm{C}, 5 \mathrm{~min}$ \\
\hline CD4 & Novocastra & $1: 10$ & Citrate buffer $\mathrm{pH}$, wet autoclave, $121^{\circ} \mathrm{C}, 5 \mathrm{~min}$ \\
\hline CD5 & Novocastra & $1: 150$ & Citrate buffer $\mathrm{pH} 6$, wet autoclave, $121^{\circ} \mathrm{C}, 5 \mathrm{~min}$ \\
\hline CD7 & Novocastra & $1: 50$ & Citrate buffer $\mathrm{pH}$, wet autoclave, $121^{\circ} \mathrm{C}, 5 \mathrm{~min}$ \\
\hline CD8 & DAKO & $1: 50$ & Citrate buffer $\mathrm{pH} 6$, wet autoclave, $121^{\circ} \mathrm{C}, 5 \mathrm{~min}$ \\
\hline CD15 & DAKO & $1: 400$ & Citrate buffer pH6, wet autoclave, $121^{\circ} \mathrm{C}, 5 \mathrm{~min}$ \\
\hline CD20 & DAKO & $1: 700$ & Aqua destillata, microwave oven, $800 \mathrm{~W}, 10 \mathrm{~min}$ \\
\hline CD30 & DAKO & $1: 50$ & Citrate buffer $\mathrm{pH} 6$, wet autoclave, $121^{\circ} \mathrm{C}, 5 \mathrm{~min}$ \\
\hline CD45RA & DAKO & $1: 500$ & None \\
\hline ALK-1 & DAKO & $1: 200$ & Citrate buffer $\mathrm{pH} 6$, wet autoclave, $121^{\circ} \mathrm{C}, 5 \mathrm{~min}$ \\
\hline EMA & DAKO & $1: 50$ & None \\
\hline LMP-1 & DAKO & $1: 1000$ & $0.1 \%$ pronase, $4 \mathrm{~min}$ \\
\hline
\end{tabular}


DNA Isolation, T-Cell Receptor $\gamma$ - and Immunoglobulin Heavy Chain Gene Rearrangement Analysis

DNA from the microdissected Hodgkin's and ReedSternberg cells was extracted in a multistep manner as described elsewhere. ${ }^{8}$ The multiplex polymerase chain reaction (PCR) analysis of immunoglobulin heavy chain- and T-cell receptor $\gamma$ gene rearrangements was performed as described previously. ${ }^{38}$ However, to increase the amount of DNA from the single-cell preparations, $1 \mu \mathrm{l}$ of the first PCR run (36 cycles) was transferred to a new tube and amplified again for 36 cycles.

\section{Statistics}

Statistical analysis was performed with the Statistical Package of Social Sciences. The Pearson's $\chi^{2}$ and the Mann-Whitney $U$-tests were used to estimate correlations between expression profiles and to compare means between groups. Diseasespecific and overall survival were analyzed by the Kaplan-Meier method and compared by the log-rank test. $P$-values below 0.05 were considered significant.

\section{Results}

\section{Histopathology}

Of 330 classical Hodgkin's lymphoma cases included in the tissue microarray, 259 (78\%) were representative. The failed analysis of 71 cases $(22 \%)$ was linked to specifications of the array technology, as described recently. ${ }^{6,34,35}$ The evaluable cases consisted of 152 nodular sclerosis, 84 mixed cellularity, nine lymphocyte-rich, five lymphocytedepleted and nine unclassifiable classical Hodgkin's lymphomas. Cores containing no tissue varied from slide to slide.

\section{Immunohistochemical Analysis of Tissue Microarray}

The immunohistochemical results obtained on the tissue microarray are shown in Table 2. Applying the above-mentioned score system, we detected 12 classical Hodgkin's lymphoma cases that expressed T-cell markers, seven expressed only one T-cell marker (mainly CD2) and the remaining five expressed up to four T-cell markers (Table 2, Figure 1). In the positive cases, a mean proportion of $40 \%$ of the Hodgkin's and Reed-Sternberg cells (range 20$100 \%$ ) stained positively for the analyzed markers, except for CD8, the latter showing a weaker expression, at an intensity comparable to the reactive background small T lymphocytes, which served as internal positive controls (Figure 2a-f). In all cases, Hodgkin's and Reed-Sternberg cells remained CD7 negative.

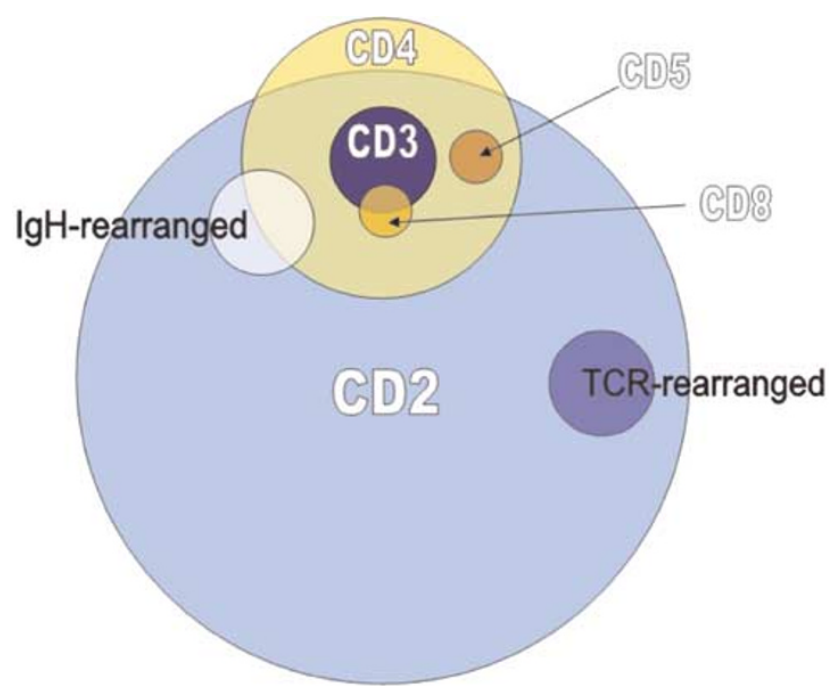

Figure 1 Proportional distribution of T-cell marker expression and clonal immunoglobulin heavy chain- (IgH) and T-cell receptor $\gamma(\mathrm{TCR} \gamma)$ gene rearrangement in Hodgkin's and ReedSternberg cells of classical Hodgkin's lymphoma. Overall, $5 \%$ of classical Hodgkin's lymphoma express T-cell markers.

Table 2 Tissue microarray analysis of T-cell marker expression in classical Hodgkin's lymphoma

\begin{tabular}{|c|c|c|c|c|c|c|c|c|c|c|c|c|c|c|c|}
\hline \multirow{3}{*}{$\begin{array}{l}\text { Hodgkin's lymphoma } \\
\text { subtype }\end{array}$} & \multicolumn{15}{|c|}{ T-cell marker expression } \\
\hline & \multirow{2}{*}{$\begin{array}{c}\text { Number of } \\
\text { cases }\end{array}$} & \multicolumn{2}{|c|}{ Any } & \multicolumn{2}{|c|}{$C D 2$} & \multicolumn{2}{|c|}{$C D 3$} & \multicolumn{2}{|c|}{$C D 4$} & \multicolumn{2}{|c|}{ CD5 } & \multicolumn{2}{|c|}{$C D 7$} & \multicolumn{2}{|c|}{$C D 8$} \\
\hline & & $\mathrm{n}$ & $\%$ & $\mathrm{n}$ & $\%$ & $\mathrm{n}$ & $\%$ & $\mathrm{n}$ & $\%$ & $\mathrm{n}$ & $\%$ & $\mathrm{n}$ & $\%$ & $\mathrm{n}$ & $\%$ \\
\hline Nodular sclerosis & 152 & 9 & 6 & 8 & 5 & 2 & 1 & 4 & 3 & & & & & 1 & 1 \\
\hline Mixed cellularity & 84 & 2 & 2 & 2 & 2 & & & & & & & & & & \\
\hline Lymphocyte rich & 9 & & & & & & & & & & & & & & \\
\hline Lymphocyte depleted & 5 & 1 & 20 & 1 & 20 & & & 1 & 20 & 1 & 20 & & & & \\
\hline Unclassified & 9 & & & & & & & & & & & & & & \\
\hline Total & 259 & 12 & 5 & 11 & 4 & 2 & 1 & 5 & 2 & 1 & 0.4 & 0 & 0 & 1 & 0.4 \\
\hline
\end{tabular}



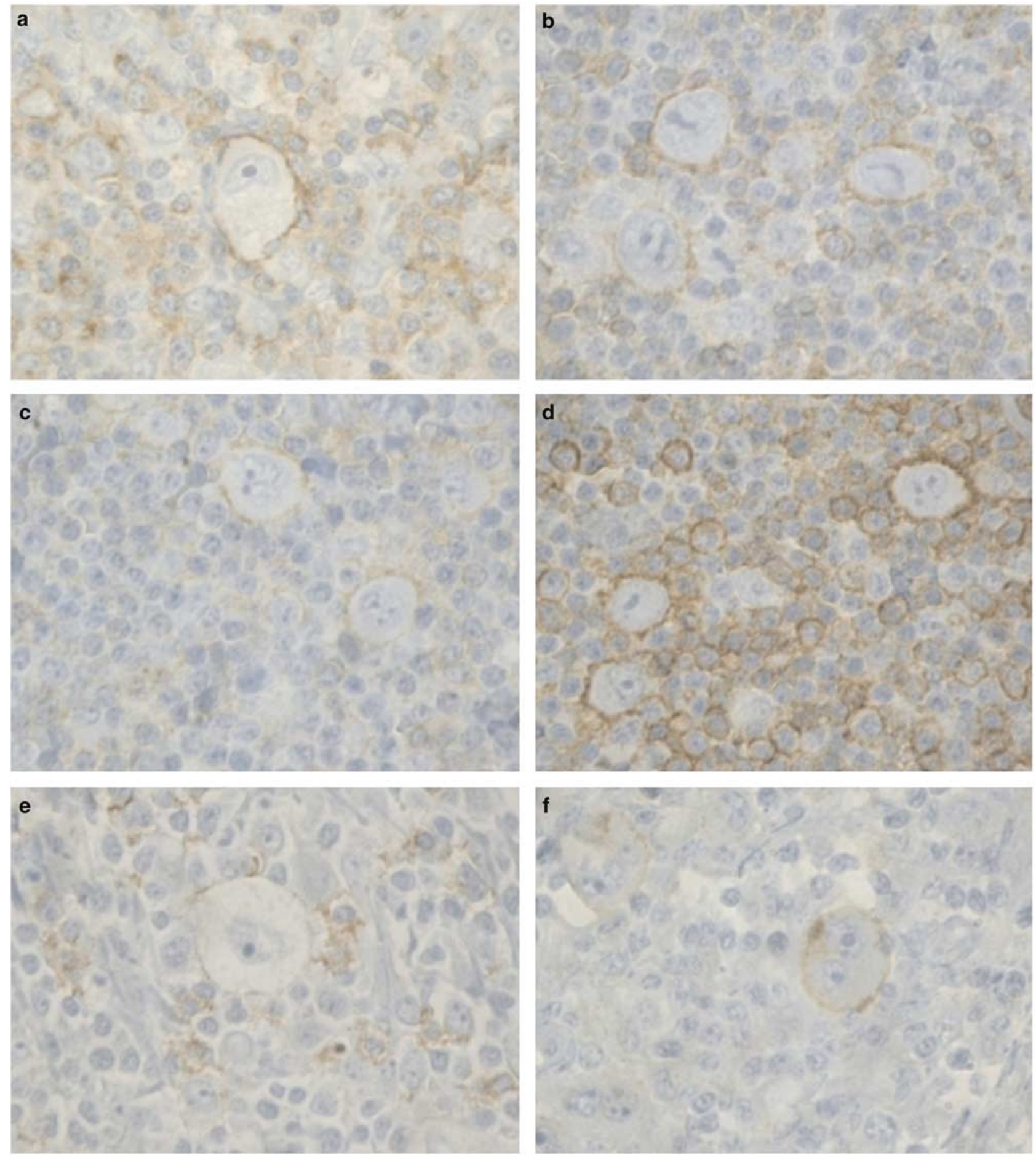

Figure 2 Expression of CD2 (a), CD3 (b), CD4 (c), CD5 (d), CD8 (e) and CD30 (f) by Hodgkin's and Reed-Sternberg cells of classical Hodgkin's lymphoma, immunoperoxidase stain, $\times 400$. Of note, the lower left case (e) shows a weak but continuous membranous staining for CD8 of the Hodgkin's cell, and the lower right case (f) represents a morphologically unequivocal BSAP-negative classical Hodgkin's lymphoma with clonally rearranged T-cell receptor $\gamma$ gene.

\section{Immunohistochemical Analysis of Conventional Sections}

The immunohistochemical profiles on the corresponding conventional sections of the T-cell marker- positive tissue microarray cases are shown in Table 3. Direct comparison showed a concordance for the results for T-cell markers as well as CD15 and CD20 of over $92 \%$ with those obtained on the tissue microarray. All T-cell antigen-positive classical 
Hodgkin's lymphoma cases were negative for ALK1, EMA and CD45RA (Table 3). Four cases (one with clonal T-cell receptor $\gamma$ - and two with clonal immunoglobulin heavy chain gene rearrangements) showed weak expression of BSAP, two stained strongly and four remained negative (one with clonal T-cell receptor $\gamma$ gene rearrangement).

\section{Molecular Analysis}

Amplifiable DNA could be isolated from 10 microdissected cases, and in seven cases, we were able to amplify the $\beta$-globin control gene. One of these cases showed a clonal T-cell receptor $\gamma$ gene rearrangement, while clonal immunoglobulin heavy chain gene rearrangement was detected in another. The remaining six cases did not show clonal peaks for either immunoglobulin heavy chain or T-cell receptor $\gamma$. In the three cases lacking an amplifiable $\beta$ globin gene, we were able to analyze amplifiable immunoglobulin heavy chain- and T-cell receptor $\gamma$ gene sequences. One such case evidenced a clonal T-cell receptor $\gamma$ gene rearrangement in Hodgkin's and Reed-Sternberg cells, suggesting possible T-cell classical Hodgkin's lymphoma origin, while the other case demonstrated a clonal immunoglobulin heavy chain gene rearrangement (Figure 3). Interestingly, both cases with clonal T-cell receptor $\gamma$ gene rearrangements were Epstein-Barr virus-negative, CD20-positive mixed cellularity classical Hodgkin's lymphomas. ${ }^{6}$

Table 3 Comparison of the expression of T-cell markers in classical Hodgkin's lymphoma on tissue microarray (TMA) and conventional tissue sections (CS) in cases with available paraffin material

\begin{tabular}{|c|c|c|c|c|c|c|c|c|c|c|c|c|c|c|c|c|c|}
\hline \multirow[t]{3}{*}{ Case } & \multicolumn{17}{|c|}{ Percent positive Hodgkin's and Reed-Sternberg cells } \\
\hline & \multirow{2}{*}{$\begin{array}{c}B S A P \\
C S\end{array}$} & \multicolumn{2}{|c|}{$C D 2(\%)$} & \multicolumn{2}{|c|}{$C D 4(\%)$} & \multicolumn{2}{|c|}{ CD3 $(\%)$} & \multicolumn{2}{|c|}{ CD5 (\%) } & \multicolumn{2}{|c|}{$C D 7(\%)$} & \multicolumn{2}{|c|}{ CD8 $(\%)$} & \multicolumn{2}{|c|}{ CD15 (\%) } & \multicolumn{2}{|c|}{$C D 20(\%)$} \\
\hline & & TMA & $C S$ & $T M A$ & $C S$ & TMA & $C S$ & TMA & $C S$ & $T M A$ & $C S$ & $T M A$ & $C S$ & TMA & $C S$ & $T M A$ & $C S$ \\
\hline $1^{\mathrm{IgH} \text { a }}$ & $1+$ & 20 & 15 & & & & & & & & & & & & 5 & & \\
\hline $2^{\mathrm{TCR} \gamma \mathrm{a}}$ & 0 & 80 & 80 & & & & & & & & & & & 15 & 10 & 20 & 20 \\
\hline $3^{\mathrm{TCR} \gamma}$ & $1+$ & 20 & 15 & & & & & & & & & & & 10 & 5 & 80 & 80 \\
\hline 4 & 0 & 40 & 40 & & & & & & & & & & & & & & \\
\hline 5 & $1+$ & 20 & 15 & 20 & 20 & 20 & 20 & & & & & & & 80 & 80 & & \\
\hline 6 & 0 & 100 & 100 & 80 & 80 & & & 60 & 60 & & & & & 10 & 5 & & \\
\hline 7 & $2+$ & 30 & 30 & & & & & & & & & & & 15 & 20 & 20 & 10 \\
\hline 8 & $2+$ & 50 & 50 & 30 & 30 & 30 & 30 & & & & & 20 & 15 & 10 & 15 & & 30 \\
\hline $9^{\mathrm{IgH}}$ & $1+$ & 40 & 40 & 50 & 50 & & & & 20 & & & & & & & 30 & 30 \\
\hline 10 & 0 & & & 30 & 30 & & & & & & & & & 10 & 5 & & \\
\hline
\end{tabular}

${ }^{\mathrm{a}}$ IgH and TCR $\gamma$ indicate cases, which evidenced clonally immunoglobulin heavy chain- (IgH) and T-cell receptor $\gamma$ (TCR $\gamma$ ) gene rearrangements in Hodgkin's and Reed-Sternberg cells.
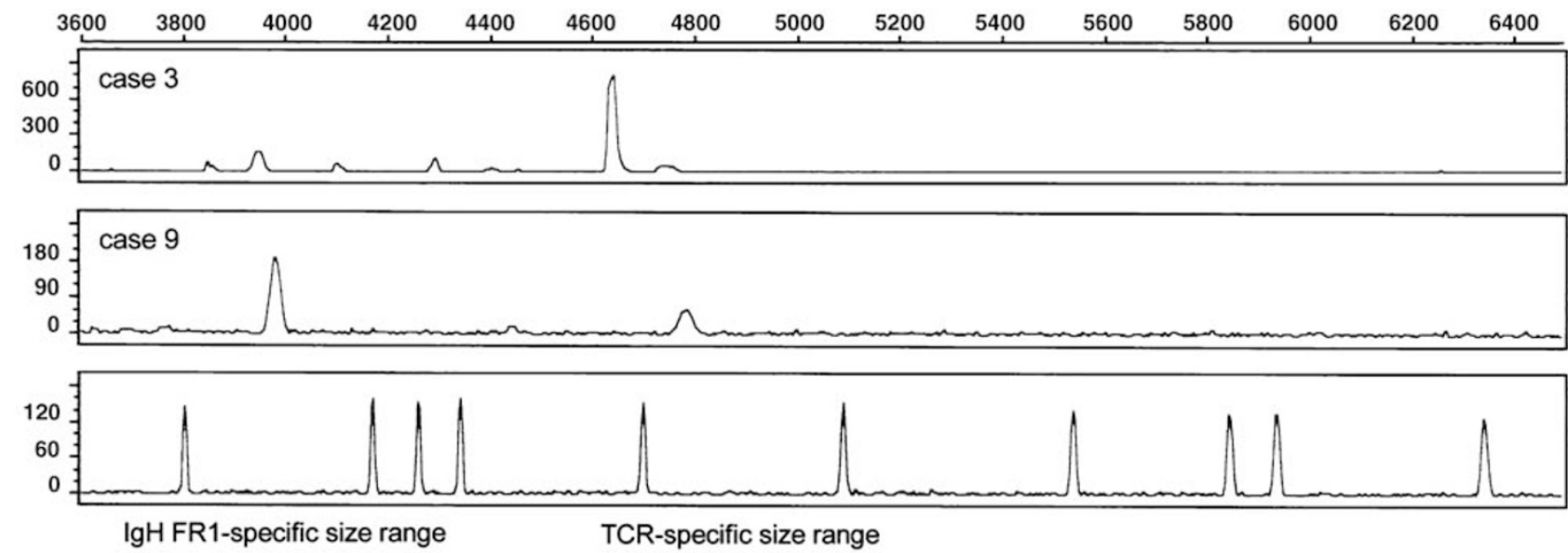

Figure 3 Analysis of microdissected Hodgkin's and Reed-Sternberg cells of classical Hodgkin's lymphoma for clonal immunoglobulin heavy chain- (IgH) and T-cell receptor $\gamma(\mathrm{TCR} \gamma)$ gene rearrangements. Fragments are aligned by size, which is indicated above the upper panel. Case 3 shows a peak in the T-cell receptor $\gamma$-specific size range, indicating a clonal rearrangement. Case 9 shows a peak in the IgH framework 1 (FR1)-specific size range, indicating a clonal rearrangement. Lowest panel—molecular weight markers. 


\section{Statistics}

T-cell marker expression did not correlate with expression of the latent membrane protein-1 of Epstein-Barr virus or with clinical parameters such as age, stage, B symptoms or bulky disease. ${ }^{35}$ Expression of T-cell markers in our classical Hodgkin's lymphoma collective was of borderline significance with respect to disease-specific survival $(P=0.0536)$. Within the mean observation period of 148 months (range 0-331) for the collective with known follow-up data, there were nine fatal events among 105 T-cell marker-negative cases (mean survival 301 months, median not reached) and one fatality among the four T-cell marker-positive classical Hodgkin's lymphoma cases (mean survival 152 months, median not reached). However, the low numbers of cases in the latter group mean that the negative association of survival and T-cell antigen expression on Hodgkin's and Reed-Sternberg cells could also be due to chance. Remarkably, the only patient with evidence of clonal T-cell receptor $\gamma$ gene rearrangement died after 41 months, which was considerably shorter than the average expectancy in the analyzed population.

\section{Discussion}

Many studies have shown convincingly that the majority of classical Hodgkin's lymphomas are of Bcell origin, although Hodgkin's and Reed-Sternberg cells express B-cell markers only in a low number of cases. ${ }^{1-3,5,6}$ T-cell marker expression in classical Hodgkin's lymphoma has also been occasionally reported, ${ }^{12-17,19,22-24,27,28}$ but classical Hodgkin's lymphoma cases of unequivocal T-cell origin are extremely rare. ${ }^{23,27}$ Using high-throughput tissue microarray technology, we investigated the largest series of classical Hodgkin's lymphomas yet analyzed for T-cell marker expression, which was found in $5 \%$ of cases in the following rank order: CD2 $>$ CD4 $>$ CD3 $>$ CD5 $>$ CD8; interestingly, $2 \%$ expressed more than one T-cell marker (Figure 1). This distribution is in line with, and considerably expands, the findings of other studies, since thus far published data were based on small collectives and lacked correlation with B-cell marker expression and clinicopathological characteristics (reviewed in Pileri et al, ${ }^{4}$ Agnarsson and Kadin, ${ }^{12}$ Cibull et $a l,{ }^{15}$ Falini et $a l,{ }^{17}$ Griesser et $a l,{ }^{19}$ Orazi et $a l^{24}$ and Seitz et $a l^{27}$ ). Direct validation demonstrated that the expression of T-cell markers on the tissue microarray matched the assessment on the corresponding conventional full tissue sections by at least $92 \%$, again indicating that the tissue microarray approach is an excellent tool to look for expression profiles on large collectives. ${ }^{6,34,35}$ Importantly, since Hodgkin's and Reed-Sternberg cells are often rimmed by T cells, antigen shedding from the latter had to be considered to rule out false positivity. Therefore, only cases with a clearcut continuous and complete membranous staining for the T-cell markers analyzed in $\geq 20 \%$ of Hodgkin's and Reed-Sternberg cells were considered positive.

Evidence of clonal T-cell receptor $\gamma$ gene rearrangements in microdissected Hodgkin's and ReedSternberg cells was found in only two T-cell antigenexpressing classical Hodgkin's lymphomas out of 259 evaluable paraffin-embedded cases $(<1 \%)$. However, we were not able to amplify the $\beta$-globin gene in three of 10 microdissected cases, probably because we analyzed single cells (75-120 cells/case) from archival paraffin-embedded tissue samples collected between 1979 and 2000. For comparison, all other studies that focused on single Hodgkin's and Reed-Sternberg cell analysis for clonal T-cell receptor gene rearrangements were performed on cells isolated from frozen tissue. ${ }^{23,27,29}$ Nevertheless, the number of our cases with genotypic evidence of possible T-cell origin from among all phenotypically T-cell marker-positive classical Hodgkin's lymphomas (two of 12) is in accord with the report of Seitz et $\mathrm{al}^{27}$ (two of 13). Our findings indicate that most Tcell antigen-positive classical Hodgkin's lymphomas aberrantly express these proteins, and only very few cases are of possible T-cell origin. Indeed, six and four T-cell marker-positive cases coexpressed the B-cell markers BSAP and CD20, respectively. Thus, the proportion of BSAP-positive cases within the T-cell marker expressing cases was lower than expected, ${ }^{37}$ while that for CD20 was in line with the general level of CD20 expression in classical Hodgkin's lymphoma, ${ }^{5}$ and particularly in the T-cell marker-negative group. Importantly, one of the classical Hodgkin's lymphoma patients (Figure 2f) with evidence of clonal T-cell receptor $\gamma$ gene rearrangement (BSAP negative) had considerably shorter disease-specific survival, indicating a need for further clinical evaluation of such cases.

The discrepancy between genotypic cell origin of classical Hodgkin's lymphoma and phenotypic expression of T- and B-cell markers can be explained by profound defects in the lineage gene expression of Hodgkin's and Reed-Sternberg cells, ${ }^{39,40}$ which can lead to 'lineage infidelity' with probable aberrant expression of markers. On the other hand, markers considered T-cell lineage specific, such as CD2, can be detected on subsets of $\mathrm{B}$ cells. ${ }^{41}$ Moreover, CD5-positive non-neoplastic B cells represent a well-defined population, ${ }^{42}$ and there is increasing evidence for T-cell marker-positive B-cell lymphomas. ${ }^{43,44}$ The same is also true for CD20 in T-cell lymphomas; ${ }^{45}$ remarkably, both our classical Hodgkin's lymphoma cases with genetic evidence of possible T-cell origin expressed CD20. Hodgkin's and Reed-Sternberg cells express CD15, which is also a T-cell activation antigen. ${ }^{46}$ Recent findings indicate that some transcription factors of B- (OCT1/BOB.1 ${ }^{47}$ or T-cell lineage (T-bet) ${ }^{48}$ can be aberrantly expressed in T-non-Hodgkin's- and classical Hodgkin's lymphomas, respectively, representing obviously a common phenomenon contributing to 
lymphomagenesis. Considering the lower number of BSAP-positive cases among T-cell marker-positive classical Hodgkin's lymphomas, an intriguing possibility is that silencing of BSAP in Hodgkin's and Reed-Sternberg cells may lead to the activation of lineage-inappropriate genes (reviewed in Nutt et $a l^{49}$ ).

What is the biological significance of T-cell marker expression in classical Hodgkin's lymphoma without genetic evidence of T-cell origin? CD2, CD3, CD4, CD5 and CD8 play an important role in T-cell receptor signaling (reviewed in Werlen and Palmer $^{50}$ ), activating the tyrosine kinases $\mathrm{p} 56^{\text {lck }}$ and p56 ${ }^{\text {fyn }}{ }^{51}$ Therefore, a possible explanation for T-cell marker expression in classical Hodgkin's lymphoma could be a futile attempt to circumvent the defective B-cell receptor expression and signaling cascade in Hodgkin's and Reed-Sternberg cells ${ }^{1-3}$ by activating alternative signaling cascades. The profound defects in lineage gene expression of Hodgkin's and Reed-Sternberg cells ${ }^{39,40}$ may also contribute to unopposed activation of lineage-inappropriate genes. Otherwise, T-cell marker expression in Hodgkin's and Reed-Sternberg cells might be induced by the distinct classical Hodgkin's lymphoma cytokine milieu. ${ }^{52}$ Finally, one could speculate that identical transformation events in both B- and T cells lead to a similar phenotypes regardless of lineage specificity.

In summary, based on comprehensive data form the thus far largest collective analyzed, we conclude that expression of T-cell markers in classical Hodgkin's lymphoma is rare; their aberrant expression on Hodgkin's and Reed-Sternberg cells of Bcell origin and T-cell histogenesis might account for the detection of T-cell markers in classical Hodgkin's lymphoma.

\section{Acknowledgements}

This work has been supported by grants from the 'Krebshilfe Tirol' to AT and AIRC-Milan to SAP. We thank M Kat Occhipinti-Bender for editorial help.

\section{References}

1 Cossman J, Annunziata CM, Barash S, et al. ReedSternberg cell genome expression supports a B-cell lineage. Blood 1999;94:411-416.

2 Kuppers R. Molecular biology of Hodgkin's lymphoma. Adv Cancer Res 2002;84:277-312.

3 Marafioti T, Hummel M, Foss HD, et al. Hodgkin and Reed-Sternberg cells represent an expansion of a single clone originating from a germinal center B-cell with functional immunoglobulin gene rearrangements but defective immunoglobulin transcription. Blood 2000;95:1443-1450.

4 Pileri SA, Ascani S, Leoncini L, et al. Hodgkin's lymphoma: the pathologist's viewpoint. J Clin Pathol 2002;55:162-176.

5 Tzankov A, Krugmann J, Fend F, et al. Prognostic value of CD20 expression in classical Hodgkin lymphoma: a clinico-pathological study of 119 cases. Clin Cancer Res 2003;9:1381-1386.

6 Tzankov A, Zimpfer A, Pehrs AC, et al. Expression of B-cell markers in classical Hodgkin lymphoma: a tissue microarray analysis of 330 cases. Mod Pathol 2003;16:1141-1147.

7 Brauninger A, Hansmann ML, Strickler JG, et al. Identification of common germinal-center B-cell precursors in two patients with both Hodgkin's disease and non-Hodgkin's lymphoma. N Engl J Med 1999;340: 1239-1247.

8 Fong D, Kaiser A, Spizzo G, et al. Hodgkin's disease variant of Richter's syndrome in chronic lymphocytic leukemia patients previously treated with fludarabine. Br J Haematol 2005;129:199-205.

9 Kuppers R, Sousa AB, Baur AS, et al. Common germinal-center B-cell origin of the malignant cells in two composite lymphomas, involving classical Hodgkin's disease and either follicular lymphoma or B-CLL. Mol Med 2001;7:285-292.

10 Tinguely $\mathrm{M}$, Rosenquist $\mathrm{R}$, Sundstrom $\mathrm{C}$, et al. Analysis of a clonally related mantle cell and Hodgkin lymphoma indicates Epstein-Barr virus infection of a Hodgkin/Reed-Sternberg cell precursor in a germinal center. Am J Surg Pathol 2003;27:1483-1488.

11 van den Berg A, Maggio E, Rust R, et al. Clonal relation in a case of CLL, ALCL, and Hodgkin composite lymphoma. Blood 2002;100:1425-1429.

12 Agnarsson BA, Kadin ME. The immunophenotype of Reed-Sternberg cells. A study of 50 cases of Hodgkin's disease using fixed frozen tissues. Cancer 1989;63: 2083-2087.

13 Al Saati T, Galoin S, Gravel S, et al. IgH and TcRgamma gene rearrangements identified in Hodgkin's disease by PCR demonstrate lack of correlation between genotype, phenotype, and Epstein-Barr virus status. J Pathol 1997;181:387-393.

14 Banks PM. The distinction of Hodgkin's disease from T cell lymphoma. Semin Diagn Pathol 1992;9:279-283.

15 Cibull ML, Stein H, Gatter KC, et al. The expression of the CD3 antigen in Hodgkin's disease. Histopathology 1989;15:599-605.

16 Dallenbach FE, Stein H. Expression of T-cell receptor beta chain in Reed-Sternberg cells. Lancet 1989;2: 828-830.

17 Falini B, Stein H, Pileri S, et al. Expression of lymphoid-associated antigens on Hodgkin's and Reed-Sternberg cells of Hodgkin's disease. An immunocytochemical study on lymph node cytospins using monoclonal antibodies. Histopathology 1987;11: 1229-1242.

18 Gledhill S, Krajewski AS, Dewar AE, et al. Analysis of T-cell receptor and immunoglobulin gene rearrangements in the diagnosis of Hodgkin's and non-Hodgkin's lymphoma. J Pathol 1990;161:245-254.

19 Griesser H, Feller AC, Mak TW, et al. Clonal rearrangements of T-cell receptor and immunoglobulin genes and immunophenotypic antigen expression in different subclasses of Hodgkin's disease. Int J Cancer 1987; 40:157-160.

20 Kadin ME, Muramoto L, Said J. Expression of T-cell antigens on Reed-Sternberg cells in a subset of patients with nodular sclerosing and mixed cellularity Hodgkin's disease. Am J Pathol 1988;130:345-353.

21 Knowles DM, Neri A, Pelicci PG, et al. Immunoglobulin and T-cell receptor beta-chain gene rearrangement analysis of Hodgkin's disease: implications for lineage 
determination and differential diagnosis. Proc Natl Acad Sci USA 1986;83:7942-7946.

22 Krenacs L, Wellmann A, Sorbara L, et al. Cytotoxic cell antigen expression in anaplastic large cell lymphomas of T- and null-cell type and Hodgkin's disease: evidence for distinct cellular origin. Blood 1997;89: 980-989.

23 Muschen M, Rajewsky K, Brauninger A, et al. Rare occurrence of classical Hodgkin's disease as a T cell lymphoma. J Exp Med 2000;191:387-394.

24 Orazi A, Jiang B, Lee CH, et al. Correlation between presence of clonal rearrangements of immunoglobulin heavy chain genes and B-cell antigen expression in Hodgkin's disease. Am J Clin Pathol 1995;104: 413-418.

25 Raghavachar A, Binder T, Bartram CR. Immunoglobulin and T-cell receptor gene rearrangements in Hodgkin's disease. Cancer Res 1988;48:3591-3594.

26 Roth MS, Schnitzer B, Bingham EL, et al. Rearrangement of immunoglobulin and T-cell receptor genes in Hodgkin's disease. Am J Pathol 1988;131:331-338.

27 Seitz V, Hummel M, Marafioti T, et al. Detection of clonal T-cell receptor gamma-chain gene rearrangements in Reed-Sternberg cells of classic Hodgkin disease. Blood 2000;95:3020-3024.

28 Oudejans JJ, Kummer JA, Jiwa M, et al. Granzyme B expression in Reed-Sternberg cells of Hodgkin's disease. Am J Pathol 1996;148:233-240.

29 Daus H, Trumper L, Roth J, et al. Hodgkin and ReedSternberg cells do not carry T-cell receptor gamma gene rearrangements: evidence from single-cell polymerase chain reaction examination. Blood 1995;85: 1590-1595.

30 Davis TH, Morton CC, Miller-Cassman R, et al. Hodgkin's disease, lymphomatoid papulosis, and cutaneous T-cell lymphoma derived from a common T-cell clone. N Engl J Med 1992;326:1115-1122.

31 Brousset P, Lamant L, Viraben R, et al. Hodgkin's disease following mycosis fungoides: phenotypic and molecular evidence for different tumour cell clones. J Clin Pathol 1996;49:504-507.

32 Simrell CR, Boccia RV, Longo DL, et al. Coexisting Hodgkin's disease and mycosis fungoides. Immunohistochemical proof of its existence. Arch Pathol Lab Med 1986;110:1029-1034.

33 Steinhoff M, Hummel M, Assaf C, et al. Cutaneous T cell lymphoma and classic Hodgkin lymphoma of the B cell type within a single lymph node: composite lymphoma. J Clin Pathol 2004;57:329-331.

34 Tzankov A, Zimpfer A, Lugli A, et al. High-throughput tissue microarray analysis of G1-cyclin alterations in classical Hodgkin's lymphoma indicates overexpression of cyclin E1. J Pathol 2003;199:201-207.

35 Tzankov A, Zimpfer A, Went $\mathrm{Ph}$, et al. Aberrant expression of cell cycle regulators in Hodgkin and Reed-Sternberg cells of classical Hodgkin lymphoma. Mod Pathol 2005;18:90-96.

36 Stein H, Delsol G, Pileri S, et al. Classical Hodgkin lymphoma. In: Jaffe ES, Harris NL, Stein H, Vardiman JW (eds). Pathology and Genetics of Tumours of the Haematopoietic and Lymphoid System. IARC Press: Lyon, 2001, pp 244-253.

37 Torlakovic E, Torlakovic G, Nguyen PL, et al. The value of anti-Pax-5 immunostaining in routinely fixed and paraffin-embedded sections. Am J Surg Pathol 2002; 26:1343-1350.

38 Meier VS, Rufle A, Gudat F. Simultaneous evaluation of $\mathrm{T}$ - and B-cell clonality, $\mathrm{t}(11 ; 14)$ and $\mathrm{t}(14 ; 18)$, in a single reaction by a four-color multiplex polymerase chain reaction assay and automated high-resolution fragment analysis: a method for the rapid molecular diagnosis of lymphoproliferative disorders applicable to fresh frozen and formalin-fixed, paraffin-embedded tissues, blood, and bone marrow aspirates. Am J Pathol 2001;159:2031-2043.

39 Hertel CB, Zhou XG, Hamilton-Dutoit SJ, et al. Loss of B cell identity correlates with loss of B cell-specific transcription factors in Hodgkin/Reed-Sternberg cells of classical Hodgkin lymphoma. Oncogene 2002;21: 4908-4920.

40 Schwering I, Brauninger A, Klein U, et al. Loss of the B-lineage-specific gene expression program in Hodgkin and Reed-Sternberg cells of Hodgkin lymphoma. Blood 2003;101:1505-1512.

41 Kingma DW, Imus P, Xie XY, et al. CD2 is expressed by a subpopulation of normal $B$ cells and is frequently present in mature B-cell neoplasms. Cytometry 2002; 50:243-248.

42 Youinou P, Jamin C, Lydyard PM. CD5 expression in human B-cell populations. Immunol Today 1999;20: 312-316.

43 Kaleem Z, White G, Zutter MM. Aberrant expression of T-cell-associated antigens on B-cell non-Hodgkin lymphomas. Am J Clin Pathol 2001;115:396-403.

44 Tzankov A, Brunhuber $\mathrm{T}$, Gschwendtner A, et al. Incidental oral plasmablastic lymphoma with aberrant expression of CD4 in an elderly HIV-negative patient: how a gingival polyp can cause confusion [letter]. Histopathology 2005;46:348-350.

45 Sun T, Akalin A, Rodacker M, et al. CD20 positive T cell lymphoma: is it a real entity? J Clin Pathol 2004; 57:442-444.

46 Chadburn A, Inghirami G, Knowles DM. The kinetics and temporal expression of T-cell activation-associated antigens CD15 (LeuM1), CD30 (Ki-1), EMA, and CD11c (LeuM5) by benign activated T cells. Hematol Pathol 1992;6:193-202.

47 Marafioti T, Ascani S, Pulford K, et al. Expression of B-lymphocyte-associated transcription factors in human T-cell neoplasms. Am J Pathol 2003;162: 861-871.

48 Dorfman DM, Hwang ES, Shahsafaei A, et al. T-bet, a $\mathrm{T}$ cell-associated transcription factor, is expressed in Hodgkin's lymphoma. Hum Pathol 2005;36:10-15.

49 Nutt SL, Eberhard D, Horcher M, et al. Pax5 determines the identity of B cells from the beginning to the end of B-lymphopoiesis. Int Rev Immunol 2001;20: 65-82.

50 Werlen G, Palmer E. The T-cell receptor signalosome: a dynamic structure with expanding complexity. Curr Opin Immunol 2002;14:299-305.

51 Burgess KE, Yamamoto M, Prasad KV, et al. CD5 acts as a tyrosine kinase substrate within a receptor complex comprising T-cell receptor $\zeta / \mathrm{CD} 3$ and protein-tyrosine kinases $\mathrm{p} 56^{\text {lck }}$ and $\mathrm{p} 56^{\mathrm{fyn}}$. Proc Natl Acad Sci USA 1992;89:9311-9315.

52 Skinnider BF, Mak TW. The role of cytokines in classical Hodgkin lymphoma. Blood 2002;99:4283-4297. 